doi: 10.52370/TISC21180DV

\title{
THE IMPACT OF PANDEMIC CORONA VIRUS ON COMMUNICATION IN TOURISM
}

\author{
Dragan Vojinović ${ }^{1}$; Nevena Kapor ${ }^{2}$
}

\begin{abstract}
Communication and information technologies have greatly influenced the changes of tourism as an activity, especially when it comes to distribution channels in tourism, achieving more accurate and closer communication with customers/tourists, easier access to information, which ultimately affected the creation of market competition with the focus on the tourist. Communication in the tourism industry is of universal importance if the goal is an adequate level of tourist satisfaction as well as competitiveness in the local and global market. Communication is not just promotional activity aimed at attracting tourists, but the totality of relationships that are realized before arrival, during staying and after the departure of tourists, and their quality determines the ratio of expected and achieved satisfaction of a service user. The aim of the research is to understand the different effects that communication (verbal and non-verbal) has in restrictive business conditions. In addition, the paper seeks to point out the practical aspects of the communication process of all participants, directly or indirectly, involved in the creation and provision of services in the tourism industry, with reference to the time of the pandemic.
\end{abstract}

Key Words: practical communication, tourism, tourist, corona virus pandemic.

JEL classification: $M 31, \mathrm{Z32}, \mathrm{M12}$

\footnotetext{
${ }^{1}$ Dragan Vojinović, Ph. D., Associate Professor, Faculty of Economics Pale, Alekse Šantića 3, Republic of Srpska, Bosnia and Herzegovina, +38757226651, draganvojinovi123@gmail.com

${ }^{2}$ Nevena Kapor, Ph. D student at Faculty of Economics in Belgrade, Assistant, Faculty of Economics Pale, Alekse Šantića 3, Republic of Srpska, Bosnia and Herzegovina, +38757226651, nevena.baricanin@ gmail.com
} 


\section{Introduction}

The service sector in the world economic trends and business environment has a dominant position in all economic processes and is an unavoidable factor in the development of society. Tourism, when defined both as an industry and as a service sector, is the fastest growing and most profitable activity, which directly or indirectly generates values for the individual, organizations, and society. Tourism is a set of individual and organized economic and trade activities, which include traffic, catering, accommodation, trade, crafts, agriculture, utilities, events and happenings. It is characterized by seasonality, heterogeneity, labor intensity, globality, a significant level of demand elasticity and supply inelasticity. Changes in economic trends, political developments, advances in technology, culture, demography, finance provide the basis for the development and progress of tourism, but at the same time carry certain risks and dangers. The changes in the tourist environment that have significantly affected the principles of business have been caused by the corona virus pandemic. The basic question was how to adapt to the new situation and how to present the tourist offer in addition to numerous administrative barriers. The attractiveness of tourism has conditioned the development of extremely strong competitive relations in national and international markets and now the conditions dictated by the pandemic have imposed a relentless struggle for consumers of tourist services.

Communication is the basic precondition for anticipating the needs and motives of tourists, promotion, source of information, attitudes, and reactions of guests. Consumers of tourist services express different, individual psychological reactions during and after consuming services, depending on expectations and perceptions, which in most cases are a subjective rather than an objective reality. Communication has a task to influence on consumer behavior, and psychological goals are related to the mental processes of consumer processing and seek to change their behavior (Grgona, 2003, p. 45). Several authors have researched the relationship between communication and psychology. Very often they neglect the social aspects of tourism, e.g., the fact that the trip gives a certain picture of a tourist, his/her personality, attitude, values, and lifestyle (Šimkova, 2014). This highlights various challenges, especially in terms of sustainability, and emphasizes the need for proper planning and management in tourism (Glaesser, et al., 2017). The paper includes research on communication in tourism and its impact on the psychology of service consumers. The aim is to investigate the effects of different types and ways of communication, 
with special reference to the advantages of direct, interpersonal verbal and non-verbal communication in restrictive business conditions. The question is which market should focus on promotion, domestic or international? How to prevent the disproportion of the 'promised and possible achievable' in conditions of 'force majeure'?

\section{Communication in tourism}

Communication is the exchange of ideas, information, signs, desires, emotions, attitudes, beliefs by verbal or nonverbal means and is an immanent factor of all human activities carried out in economic, noneconomic or personal activities (Vojinović \& Petković, 2019). Communication is connected to living organisms, especially to human beings, but it is also inherent in organizations, so it can be said that without communication, economic organizations cannot exist or achieve their business goals. Certain traits and behaviors that are characteristic of an individual are found and applied to organizations that are "the same as living organisms" (Adižes, 1988, p. 13). The term communication comes from the Latin word communicare, which in translation means to communicate or make common (share with others). For tourism and tourism service providers it is extremely important, moreover crucial to determine communication as "sharing with others", because tourism services do not have a physical dimension, are intangible, virtual, volatile, labor intensive and in most cases require presence and direct contact between provider and customer. Communication can be internal and external communication, communication before the arrival of the tourist, communication during the stay of the guest and communication after the departure of the guest.

There are various forms and ways of communication that arose and developed in accordance with the evolution of human beings and social relations, whose work is studied in law, sociology, economics, psychology, and theology. The most important and most analyzed type of communication is market or business communication, which combines economic, legal, sociological, and psychological standards of communication between people as individuals and social groups. Communication is not a one-way flow of information (Smith, 2002, p. 63). Communication with the market implies the exchange of messages between companies and interested audiences (customers, employees, shareholders, media representatives, governmental and non-governmental organizations, interest groups, etc.) on issues related to marketing and 
business success of companies (Aćimović et al., 2006, p. 326). Today, communication represents an interactive dialogue between a company and its clients (Kotler, et al., 2010, p. 541). In the literature, the tourist market is most often defined as a market of a special kind, i.e., a market $\sim$ sui generis , (Popesku, 2018, p. 43) and as such highlights the importance of communication in the tourism industry, especially marketing. A tourist product, as a set of individual products and services, is the result of the work of economic and non-economic activities. A tourist, as a specific service user of the tourist industry, rightly expects that the tourist product fully satisfies his needs and desires, regardless of whether they are common or whimsical (Bošković \& Vukčević, 2000). Tourists need information from various sources before making a purchase decision to prevent the emergence of post-purchase cognitive dissonance. Every contact with the guests is also an opportunity to present both the seller and the offer in the right light. (Baričanin \& Kapor, 2017, p.395).

There are basically two options for searching for information. In an internal search, the customer first re-examines his own memory of products that could help him solve the problem (Dibb, et al., 1991, p. 117). If they do not have enough memorized, internal information or gained experience about the product or tourist destination, they start the process of collecting information from the external environment, which is already a communication process. Demand in tourism is moving towards supply and the basic task of tourism business entities is to provide adequate, timely and accessible information. How and in what way to do it? In order to anticipate the needs of consumers and form an offer that will be exposed in communication, it is necessary to understand the behavior of the consumer of a product or service, whether it is a customer or a consumer. Knowledge of consumers requires an understanding of the principles of behavior that guide consumer behavior. (Hawkins \& Mothersbaugh, 2010, p. 15). The complexity of the communication process in tourism requires planned strategies that should provide answers to the basic questions: 'Who will say something? What will he say? How can he say that? Who will he tell that to? 'All activities in the process of providing tourist services represent communication in a certain way, but "non-communication" is also a certain type of communication. Therefore, there is an opinion that communication is "the most important and most used skill in tourism" (Fox, 2006, p. 164).

Consumer behavior, on whose attitude the business success of a company depends, is the most intriguing area of economic observation and study. It is an interactional relationship and the result of a conflict of interest 
between providers and consumers. In the process of communication, we can know the intentions and reactions of consumers, but we can also influence their behavior. Communication is an amalgam of all activities and the result of their action in direct, indirect, physical, or virtual connections with the environment. Communication - information factors can be classified into three groups of sources: commercial or marketing communications, public sources of information, and independent sources, i.e., sources that assimilated information during the use of tourist services. We emphasize that every contact of tourist organizations with their clients leads to communication, i.e., exchange of information, attitudes, impressions, and knowledge.

Figure 1: Effects of the communication process

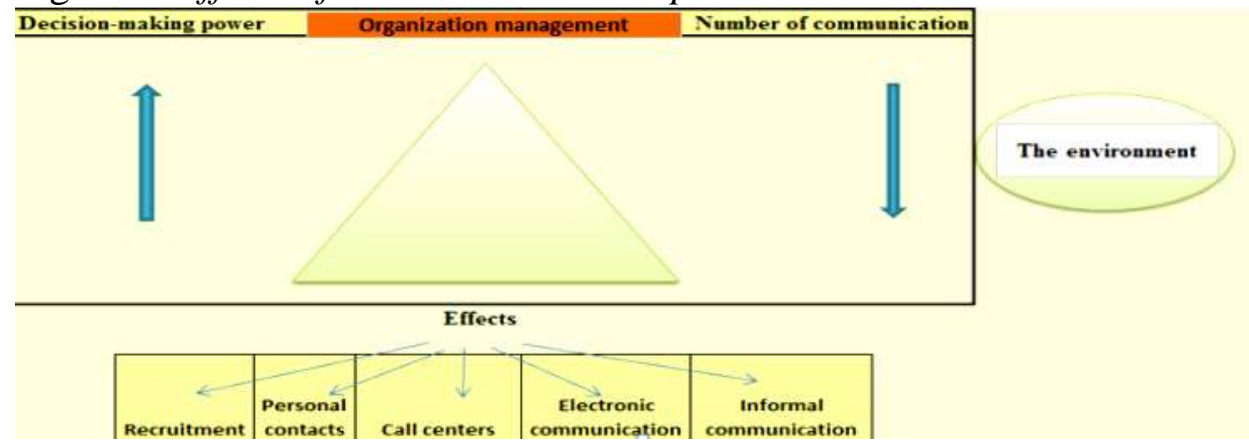

Source: Author's processing

Looking at Figure 1, it can be concluded that the dimensions of decisionmaking and communication have the opposite direction. The decisionmaking power is stronger and greater towards the top of the pyramid, while the communication is much more pronounced at the bottom of the pyramid together with the effects that the stated dimensions cause. Effects in the form of employment, personal contacts, call centers, e-communication and informal communication play a noticeably big role when observing the communication process, which is influenced by both external and internal environment with all its positive and negative forces. The relationship between decision-makers and graduates ends on the basic marketing principle of 'satisfied employee, satisfied customer'. According to the employees, not only obligations should be delegated, but also authorizations so that communication with tourists would be in the function of achieving guest satisfaction, whether it is the time of the pandemic or not. Fill $(2005$, p. 5) defines marketing communication as a management process through which an organization establishes contact and builds relationships with its various target groups. Belch $(2004$, p. 8) talks about 
coordinating different promotional elements that communicate with clients. The term marketing communications in tourism means all commercial sources of information provided by organizations or individuals, directly or indirectly, in order to effectively promote and sell tourism products and services. Marketing communications are a necessity for both providers and consumers and they "represent a means by which companies try to inform, persuade and remind consumers directly or indirectly about the products and brands they sell" (Kotler \& Keller, 2006, p. 536). From a theoretical and practical approach, special attention should be paid to integrated marketing communications, where according to Hulbert no message contradicts the other, but mutually support or complement each other, they are consistent, and redundancy is limited to the level considered as appropriate (Hulbert, et.al, 2003, p. 38). The optimal, i.e., ideal setting of communication elements is that the effectiveness of the elements should be integrated into their joint action, which will be greater than the sum of their individual actions (Vasiljev \& Vojinović, 2016, p. 88). Communication in tourism should be viewed and built as a system, which sends or communicates a convincing, clear, consistent, reliable, and specific message. The fragmentation of the world tourist market, media development, global competition, technological progress of electronic communications, development and availability of transport means lead to repositioning the relationship between tourists and the tourism sector and a significant shift in profiling marketing communications. Traditional ways of communication and media propaganda, as the dominant, and often the only instrument of the marketing concept, are slowly emerging and giving way to integrated communications with the internal and external environment. Advertising in tourism during the pandemic was supplemented only with information on the current conditions of providing tourist services, i.e., the obligations of both providers and consumers. All forms and modes of commercial, traditional adverts have not been changed.

First source of information are public sources of information on tourism, tourist services, quality of products and services, their impact on human health and the environment, and the ways and conditions of work and implementation of the tourism industry. Groups of information that tourists need and that ultimately determine their decision-making should be put in the first place. Tourists pick tourist product-service, destination, and time in accordance with their needs and preferences, but it is necessary to ensure the safety and security of visitors to a particular area, in addition to material and psychological satisfaction. 
It is certain that the movement of people - travel and stay in other destinations, whether there are previous experiences or not, carries with it certain risks that should be avoided, or their effects reduced. The laws governing the field of tourism determine the behavior of all participants, they contain dispositions and sanctions which prescribe the ways of performing this activity, and, also, the ways of using the services. Legislation is under jurisdiction of the country, but its effect on the awareness, expectations, and perceptions of consumers of tourist products and services is subject to research in sociology, psychology, and marketing. The first encounter of foreign tourists with the tourist offer of a country is the administrative or border line of crossing the state border. In theoretical terms, laws and all other legal regulations should provide solutions that will enable the development of the tourism industry, with measures to protect the participants of the receptive and emotional market.

Rules containing legal solutions need to be implemented in practice, but it happens that there is a discrepancy between the declared legal solutions and the perception of those who should implement those solutions. Theoretically and practically observed regulations and their implementation should be harmonized with tourism policy and goals, communication opportunities, language differences, cultural values, technologies, international regulations and standards, as well as political and demographic trends. Imposing laws without adequate application in practice will not contribute to the development of tourism.

The Law on Tourism of the Republic of Srpska defines tourist agencies as companies for organization, sale and implementation of tourist package deals, excursions, field trips and other forms of travel, as well as provision of other services common in tourist traffic, for profit. The Law also defines tourist organizations as associations that are established to promote and develop awareness of the importance of tourism, its effects on economic, social, cultural, and multiplicative impact on the entire economic system, also improving the general conditions of tourist service and providing information to tourists. (Law on Tourism, 2017).

States at the national level themselves enact laws to control tourism, i.e., participants, and in this process sometimes neglect rights and freedoms, often without considering internationally recognized rules and standards, which are defined by international conventions, regional and bilateral agreements. The International Conference on Tourism in the Hague (1989) states that "safety, protection of tourists and respect for dignity are a 
necessary condition for the development of tourism". (The Hague Declaration on Tourism, 2020).

Failure to comply with the law leads to serious problems in tourism. How to reconcile the obligations and rights of tourists? How, whether and to what extent to sanction violations of dispositive norms by tourists? Any disagreement on this issue will create a negative perception among tourists, which will directly affect its further development. The practical implementation of legal solutions can be a greater challenge than just the theoretical definition since it is the responsibility of persons and institutions that are not directly involved in the implementation of tourism. Communication is crucial, not only when it comes to broadcasting information, but also when applying and enforcing legal solutions.

The second source of information are domestic and international statistical, scientific, health, sports publications, bulletins with quantitative and qualitative indicators on tourism, radio and TV shows. Holders of the tourist offer try to build the most favorable opinion of the general public about their activities, work, goals, products and services. On the other hand, as tourism is not a special or separate economic branch, its development and success are the sphere of interest of all social subjects. There are national and local tourism organizations, tour operators, travel and travel agents, business associations and chambers, health facilities, sports organizations, government agencies and representative offices in the country and abroad. According to health instructions, the focus is on the obligatory behavior of tourists, and the principles of using services that are aimed at the safety and security of all participants in the tourist market.

The third source is information that a tourist can collect, obtain, or exchange with people who have experience and who have created perception after consuming tourist products and services. Most often, they are members of reference groups, friends, relatives, and acquaintances. Their importance in the process of choosing an alternative and final decision-making among tourists, have a primary position, although they are classified in the third group. Tourists have the greatest confidence in the authenticity of the experience in this source of information. These sources are often characterized as "independent" where there is a shortage of experts, paid advertisers, rented space, sponsorship, and the subjective reality of the experience. For all actors in the tourism industry, theoretically and practically, this is the most important segment of the process in providing tourism services. The success of the tourism industry depends on 
understanding and accepting the personality of the tourist, which should be motivated by the desire to feel "at home" in all tourist interactions. Tourism, unlike other industries, is strictly tied to the consumer. All results and successes are achieved by people, so employees need to be educated and motivated on a daily basis, in order to fully accept the needs and desires of guests and respond to them. Communications, thanks to advances in technology, have managed to present the tourist offer to the market and answer all questions (electronic reservation systems, online platforms), regardless to all difficulties caused by the pandemic in the tourism sector.

The communication which is taking place in the present time will have effects in the future. It will transmit good and bad impressions, but it should be recognized that a bad impression is transmitted faster and to a greater extent. Therefore, the importance of communication should not only be declared, but it must also be used in practice. Communication is not just an exchange of words. Companies should pay attention to the behavior of employees, their tidiness, work clothes, answering the phone, electronic communication, active listening, accepting complaints and taking responsibility for them, body movements, gestures, respect for working hours, taking on responsibilities of other employees, speed and accuracy of requirements, and receiving guests. Accessibility, professionalism, culture, and helpfulness of workers who are in direct communication leads to initial satisfaction with the service; service users get the feeling that they are important, that their needs are important and that the person who welcomed them will do everything 'to make their trip the best trip ever'. (Baričanin \& Kapor, 2017, p. 399). Tourists will process information from different sources, but their decision will be conditioned by the strength of the arguments of individual sources and the optimal combination of expected values and obtained values.

The corona virus pandemic has shown that communication is not just a business marketing tool. The importance of technological solutions cannot and should not be diminished. Understanding, empathy, smile, help and support are the characteristics of a human being that gain in importance in non-routine, crisis times. With an adequate approach to the guest, especially with communication, the consequences of a pandemic can be reduced to a greater extent. Tourism is 'vulnerable', but at the same time there is no other sector or activity that adapts more quickly to the new situation. Positive experiences of users of tourist services, which are passed to other tourists in crisis situations, gain new value. This value is reflected in the joint overcoming of the problem caused by the corona virus 
pandemic. Human understanding and a human smile cannot be reimbursed. Communication cannot ever have only a commercial purpose.

\section{Corona virus pandemic and communication in Bosnia and Herzegovina}

The corona virus has caused a large decline in revenue, as well as problem with liquidity for companies that are characterized as tourism companies. They all suffer huge losses together, and it is still not clearly defined when the uncertain future will become certain. According to a report by the World Trade Organization (2020), international tourism is estimated to have declined by about $60 \%$ during the corona virus pandemic, predicting a $60 \%$ to $90 \%$ reduction in bookings. Looking at Bosnia and Herzegovina, tourism quite 'flourished' in the period from March 2020 to March 2021 compared to European destinations, which were locked in that period. It is known that Bosnia and Herzegovina, during the restrictions in many surrounding countries, allowed the unhindered entry of foreign tourists, and domestic tourists could certainly visit tourist destinations in Bosnia and Herzegovina and neighboring countries (with a negative PCR test). The local municipality of Pale has been visited by 38,420 tourists in 2020, which is $24.5 \%$ less than in 2019 . The average reduction in the number of arrivals of foreign tourists was around $30 \%$, so the number of foreign tourist arrivals in 2020 has been lower by 29\% compared to 2019. Compared to 2019 the number of overnight stays by foreign tourists was lower by $17.5 \%$ and compared to 2019 the number of arrivals of domestic tourists was lower by $21 \%$. It is interesting to note that the decrease in domestic and foreign tourists in the observed period of the corona virus pandemic was very similar, despite the restrictions that countries accepted in order to prevent the spread of the virus. Tourism will continue to be influenced by globalization and different situation, perhaps even above the average of other sectors of the economy, because it is mostly related to connecting, moving, communication and creating new memories (Kapor \& Baričanin, 2016, p. 461).

Consumers are changing their habit from face-to-face communication to online communication because they are prevented from moving and communicating with company staff. In this regard, companies reacted to the change in the environment caused by the corona virus. The change caused the fact that about $80 \%$ of consumer-company communication took place remotely, via online communication, and it was a key step in bringing the product closer to customers/consumers. The communication in the 
service sector becomes more intense between tourist destinations and service users. The term more intensive refers to the responsibility of hotels and other accommodation to inform visitors about valid restrictions (if they are not informed) that apply at a tourist destination: about the working hours of certain facilities, and the impossibility of using certain facilities that exist at a tourist destination. However, it is concluded that tourism communication must be flexible and adaptable to a changing and complex environment. Lau (2020) further defines that new technologies are used to mitigate the impact of a pandemic, which will optimize innovation performance, brand awareness, and reduce security risk. Recovery, promotion and reputation plans of tourist destinations must be designed in the short and medium term, without losing sight in the longer term, in order to prepare for a new social scenario that will have different effects on consumption and travel. In that sense, it is important to work in coordination with the entire system of tourist communication, because the crisis caused by the corona virus provides an opportunity to redefine the formats of marketing campaigns in order to recover publications that are fundamental channels for the tourist value chain.

\section{Research methodology}

Out of a total of 140 forwarded questionnaires, 62 respondents successfully and correctly answered the questions. Respondents were provided with an electronic survey questionnaire, as one of the most efficient ways of collecting data in today's world. Data were collected in the timeframe from June to September 2020 in Bosnia and Herzegovina, municipality East Sarajevo. The survey questionnaire was anonymous, and all data collected are strictly confidential and will be used only for research purposes.

Table 1: Basic dimensions of research

\begin{tabular}{|c|c|c|c|c|c|}
\hline Guest type & Total & Gender & Total & Age structure & Total \\
\hline Domestic guest & 40 & $\mathrm{M}$ & 23 & $\mathrm{a} / 18-25$ & 15 \\
\hline Foreign guest & 22 & $\mathrm{~F}$ & 39 & $\mathrm{~b} / 25-35$ & 27 \\
\hline & & & & $\mathrm{c} / 35-50$ & 13 \\
\hline & & & & $\mathrm{d} / 50-65$ & 6 \\
\hline & & & & $\mathrm{e} / 65$ and more & 1 \\
\hline
\end{tabular}

Source: Author's processing

Respondents were divided by size, foreign/domestic guests, by gender and by age structure. The reason why the authors aspired to such dimensions was in the fact that the communication and the first experience of the tourist 
starts with the border guard. This communication is of key importance, especially during the corona virus pandemic, because from that moment on, tourists start to enjoy it with enthusiasm and desire. The largest number of respondents used domestic tourist services (64.52\%), while more than one third of respondents used foreign tourist services. $37.1 \%$ of the participants in the study were male, while $62.9 \%$ were female. The largest number of respondents is middle-aged, i.e., from 25-35, which can be seen from Table 1.

Table 2: Main motives for the trip (in\%) * (it is possible to circle more answers)

\begin{tabular}{|c|c|c|c|}
\hline Motives for trip & Total & Motives for trip & Total \\
\hline Rest & 39 & $\begin{array}{c}\text { getting to know new } \\
\text { destinations }\end{array}$ & 20 \\
\hline sports and recreation & 7 & previous visits & 6 \\
\hline natural attractions & 17 & retell to others & 2 \\
\hline good prices & 7 & health reasons & 8 \\
\hline cultural and historical sights & 14 & manifestations and event & 6 \\
\hline
\end{tabular}

Source: Author's processing

The main motives for travel relate to the way tourists behave in accordance with their attitudes before, during, but also after the trip. Knowledge of travel behavior can help with creating marketing programs which is related to increase the number of visitors. As can be seen, Table 2 discusses the basic motives for traveling, and among them, vacation and getting to know new destinations stand out. Tourism allows getting to know new destinations better, as well as to notice all the natural attractions and cultural - historical sights that the destination provides to visitors.

Table 3: Legal procedures

\begin{tabular}{|c|c|}
\hline Knowledge of legal procedures & \% \\
\hline Yes & 51.61 \\
\hline No & 48.39 \\
\hline
\end{tabular}

Source: Author's processing

It is certainly desirable and necessary for tourists to know basic information about legal norms, and the research concludes that there were more informed tourists in tourist destinations than uninformed ones. 
Table 4: Problems entering the country

\begin{tabular}{|c|c|}
\hline $\begin{array}{c}\text { Did you have problems entering the country during the } \\
\text { corona virus pandemic? }\end{array}$ & $\%$ \\
\hline Yes & 6.45 \\
\hline No & 93.55 \\
\hline
\end{tabular}

Source: Author's processing

The positive finding mentioned in the research is that tourists did not have much trouble crossing the border during the corona virus. The most respondents answered with NO (93.55\% in total) to the question: Did they have trouble getting to a foreign country? First positive connection between a foreign country and tourists who visit a tourist destination again or for the first time is one of the crucial things for tourism.

Table 5: Satisfaction of users of tourist during the corona virus

\begin{tabular}{|c|c|c|c|c|c|}
\hline $\begin{array}{c}\text { Are you satisfied with } \\
\text { the reception, } \\
\text { kindness and } \\
\text { communication with } \\
\text { the staff in the } \\
\text { accommodation } \\
\text { facility? }\end{array}$ & $\%$ & $\begin{array}{c}\text { Did you receive } \\
\text { additional } \\
\text { information } \\
\text { about the tourist } \\
\text { offer and } \\
\text { services? }\end{array}$ & $\%$ & $\begin{array}{c}\text { Did they } \\
\text { "recognize } \\
\text { " you on } \\
\text { arrival? }\end{array}$ & $\%$ \\
\hline a/ yes & 83.87 & a/ yes & 54.84 & $\begin{array}{c}\text { a/ yes- a } \\
\text { pleasant } \\
\text { surprise }\end{array}$ & 32.26 \\
\hline b/ no & 9.68 & b/ no & 45.16 & $\begin{array}{c}\text { b/ not- as if } \\
\text { I hadn't } \\
\text { been a guest } \\
\text { before }\end{array}$ & 62.9 \\
\hline c/ they weren't even \\
there
\end{tabular}

Source: Author's processing

Although very few respondents answered that they were not satisfied with communication (16.03\%) it is interesting to note that almost half of respondents did not receive any additional information about tourist offer which points to the conclusion that customers do not expect to get information at all. Even though there was a small percentage of those who did not have any communication with staff, it is something that should be further minimized. During the pandemic, establishing additional communication with the guest/tourist/consumer of tourist services in the 
percentage of $45.16 \%$ is very problematic. Although it might not seem to be a big problem, it worsens greatly the visitor's image of the entire tourist destination. In the long run, this way of doing business would negatively affect the finances of the facilities. $32.26 \%$ of the answers in the empirical research were affirmative, i.e., guests were recognized by staff, routine guest - reception communication amounted to $62.90 \%$, while $4.84 \%$ of tourists had no positive experience in terms of communication and reception by hotel staff. It is important for management and hotel staff to focus on some of the following tips aimed at making guests feel special. On the other hand, hotels face a number of problems in recognizing each guest individually. Hotels, especially in the luxury area, want to provide personalized services to their guests. But there is a problem with recognized staff turnover rates in the industry averaging as much as 30 percent. The reception staff must provide a feeling of sincere welcome upon arrival at the hotel and offer to help if the guest has a problem on arrival or during their stay at the hotel. The reception staff should emphasize their name, or better surname, also communication with tourists during the stay should be specific, clear, and without much 'wandering'.

Table 6: Guest address and staff characteristics

\begin{tabular}{|c|c|c|c|}
\hline $\begin{array}{c}\text { The way the guest is } \\
\text { addressed. }\end{array}$ & $\boldsymbol{\%}$ & $\begin{array}{c}\text { Basic characteristics of } \\
\text { staff }\end{array}$ & $\boldsymbol{\%}$ \\
\hline a / by name & 30.65 & $\mathrm{a} /$ politeness and kindness & 80.65 \\
\hline $\mathrm{b} /$ surname & 29.03 & $\mathrm{~b} /$ informative & 43.55 \\
\hline $\mathrm{c} /$ name and surname & 16.13 & $\mathrm{c} /$ pleasant voice and speech & 4.20 \\
\hline $\mathrm{d} /$ none & 24.19 & $\mathrm{~d} /$ accuracy & 19.35 \\
\hline & & $\mathrm{e} /$ care & 16.13 \\
\hline & & $\mathrm{f} /$ tact & 12.90 \\
\hline & & $\mathrm{g} /$ sincerity & 9.68 \\
\hline & & $\mathrm{h} /$ prone to cooperation & 8.06 \\
\hline
\end{tabular}

Source: Author's processing

Addressing the guest upon arrival at the hotel is the first step to guest's satisfaction. It calls into question the way the receptionist communicates with guests visiting the location. If the communication is not adequate, the sociological feeling of 'belonging' of the tourist at a given location is also questionable, and this certainly increases the practical psychological feeling of insecurity and dissatisfaction. The employees and the hotel management should pay as much attention as they can to tourists in order to increase their satisfaction. 
Table 7: Gained trust and communication during the visit to the destination (during COVID-19)

\begin{tabular}{|c|c|c|c|}
\hline $\begin{array}{c}\text { Have you established } \\
\text { communication with the } \\
\text { managers of the accommodation } \\
\text { and catering facility? }\end{array}$ & $\%$ & $\begin{array}{c}\text { During my stay I } \\
\text { gained confidence in: }\end{array}$ & $\%$ \\
\hline a/ yes & 33.87 & a / employees & 46.77 \\
\hline b/ no & 66.13 & b / company & 22.58 \\
\hline & & c/ I did not gain trust & 30.65 \\
\hline
\end{tabular}

Source: Author's processing

The communication channel from top to bottom should be perfect in tourist companies, especially because it is very important what kind of communication tourists have with tourist companies. The communication of the manager with the guests should be improved, because the tourists then acquire a sense of importance, that their stay is really purposeful, and that the management and the staff are really happy because the tourist chose that hotel. The question, which refers to the degree of trust, shows a picture of a gap that tourist facilities must overcome. These are things that tourist facilities have to repair in order to survive, because their job depends on the trust they gain in people, who become loyal customers, and visit the destination every year.

\section{Conclusion}

In the age of digitalization travelers, hotel and restaurant guests are increasingly looking for emotions and unique experiences. Today's guests are not only looking for a 'roof over their heads' or delicious food, but they are also constantly looking for a new experience. Emotions are recognized as one of the most important factors for the individual enjoyment of guests. The rapidly changing context in the modern tourism and hospitality industry has led to an increased emphasis on communication strategies, together with responding to the needs of increasingly demanding consumers, and with the fragmented nature of the marketing and media environment. Practice and theory related to this industry are explained and criticized by using modern case studies. Even in this so-called "age of communication", the workplace in hospitality and tourism is still filled with endless worries related to communication. The hospitality and tourism workplace are people-oriented because it is focused on providing excellent service to targeted service users. The tourism sector uses human resources to carry out activities and daily commitments. In a service-oriented 
industry, everyday work requires a continuous flow of information that should deliver information quickly, accurately, and efficiently through the most appropriate medium. Constant interaction and close coordination among employees are a must. Teamwork of all employees is crucial to fulfill the guest's satisfaction, as well as hotel service to exceed their expectations, and it also should enable things to be done quickly and according to standards. All this requires efficient and simple business communication.

Research conducted among users of tourist services has shown that communication is one of the most important factors influencing the overall picture of a tourist destination. Employees, as the most important link between a company and its customers, are crucial in the development and implementation of efficient communication systems. First-line employees must ensure that they are fully aware of the policies and priorities that the company prefers, and they must also know where and how to obtain information if necessary. Employees must also react positively to the unexpected. Staff should also be fully trained to perform all of their work tasks. Communication with customers is a winning business strategy in the service sector, and it also needs to be maintained at a certain level, which will ensure that their customers keep coming back. For this reason, one should never underestimate the communication system which is crucial to an organization's success in hospitality and tourism. When communication during the pandemic is observed, it can be concluded that the corona virus has greatly affected tourism as an activity, i.e., there have been quantitative and qualitative changes. It can be concluded that the corona virus independently segmented the tourist market, and disabled tourist facilities to work according to a pre-established plan. By observing the communication, conclusion can be drawn that communication has become much more intense between tourist facilities and tourists than it was before, and that intensity will be further increased in future.

\section{References}

1. Aćimović, S., Jakšić, M., Backović, M., Cerović, B., Medojević, B. (2006). Ekonomski rečnik [Economic vocabulary]. Beograd: Centar za izdavačku delatnost Ekonomskog fakulteta u Beogradu.

2. Adižes, I. (1988). Životni ciklusi preduzeća, kako i zašto preduzeća rastu $i$ umiru $i$ kako ih lečiti [Life cycles of companies, how and why companies grow and die and how to treat them]. NIP Politika, Belgrade. 
3. Baričanin, N., Kapor, V. (2017). 7P marketing miks kao preduslov za visok kvalitet usluga u turizmu [7P marketing mix as a prerequisite for high quality services in tourism]. Jahorinski poslovni forum, No. 6, 395-399.

4. Belch, G., Belch, M. (2004). Advertising and Promotion - An Integrated Marketing Communications Perspective, $6^{\text {th }}$ Edition, McGrave-Hill, New York.

5. Bošković, D., Vukčević, M. (2000). Tržišno komuniciranje u funkciji razvitka hrvatskog jadranskog turizma [Market communication in the function of the development of Croatian Adriatic tourism]. Pomorski zbornik, Vol. 38, No. 1.127-141.

6. Dibb, S., Simkin, L., Pride, M., Ferrell, O. (1991). Marketing. Mate, Zagreb.

7. Fill, C. (2005). Marketing Communications: Engagement, Strategies and Practice, Prentice Hall, England, Harrow.

8. Fox, R. (2006). Poslovna komunikacija [Business communication]. Croatian University Press, Zagreb.

9. Glaesser, D., Kester, J., Paulose, H., Alizadeh, A. (2017). Global travel patterns. Journal of Travel Medicine, Vol. 24, No. 4, 1-5.

10. Grgona, J. (2003). Imidž turističke destinacije: prilog znanstvenoj raspravi [The image of a tourist destination: a contribution to the scientific discussion]. Acta Turistica, Vol. 15, No. 1. 38-60.

11. Hawkins, D., Mothersbaugh, D. (2010). Consumer behavior: Building marketing strategy. McGraw-Hill, New York.

12. Hulbert, M. et all. (2003). Total integrated marketing breaking the bounds of the function. Free Press, New York, 38.

13. Kapor, V., Baričanin, N. (2016). Strukturni problemi turističkih destinacija $\mathrm{u}$ vansezonskom periodu [Structural problems of tourist destinations in the off-season]. Jahorinski poslovni forum, No. 5, 461. 
14. Kotler, P., Bowen, J., Makens, J. (2010). Marketing u ugostiteljstvu, hotelijerstvu i turizmu [Marketing in catering, hospitality and tourism]. Mate, Zagreb.

15. Kotler, P., Keller, K. (2006). Marketing menadžment [Marketing management]. Data status, Beograd.

16. Lau, A. (2020). New technologies used in COVID-19 for business survival: Insights from the Hotel Sector in China. Information Technology \& Tourism, Vol. 22, 497-504.

17. Law on Tourism. (2017). "Official Gazette of RS" No. 45/2017, article 20, 65 clause 3 and 4 .

18. Popesku, J. (2018). Marketing u turizmu i hotelijerstvu [Marketing in tourism and hospitality]. Caligraph, Beograd.

19. Šimkova, E. (2014). Psychology and its application in tourism. Procedia - Social and Behavioral Sciences, Vol. 114, 234-238.

20. Smit, P. (2002). Marketinške komunikacije-integralni pristup [Marketing communications-an integrated approach]. Clio, Beograd.

21. The Hague Declaration on Tourism, http://www.univeur.org/cuebc/, (25 September 2020).

22. Vasiljev, S., Vojinović, D. (2016). Upravljanje marketingom [Marketing management]. CID, Ekonomski fakultet Pale.

23. Vojinović, D., Petković, K. (2019). Poslovno komuniciranje elektrodistributivnog preduzeća sa tržištem [Business communication of an electricity distribution company with the market]. ERS, No. 31.

24. World Trade Organization. https://www.wto.org/, (25 November 2020). 